\title{
Alteration of Seedstalk Development, Seed Yield, and Seed Quality in Carrot by Varying Temperature during Seed Growth and Development
}

\author{
Mustafa M.A. Elballa ${ }^{1}$ and D.J. Cantliffe \\ Horticultural Sciences Department, IFAS, University of Florida, Gainesville, FL 32611
}

\begin{abstract}
Additional index words. germination, Daucus carota, seed production, seed vigor, accelerated aging
Abstract. The effect of temperature on seedstalk development, seed yield and quality in carrot (Daucus carota $\mathrm{L}$.) was investigated in growth chambers at constant day/night temperatures of 33/28, 28/23, 25/20, 23/18, 20/15, and 17/12 ${ }^{\circ} \mathrm{C}$. Days to flowering, seedstalk height, number of umbels, and seed yield decreased linearly with increasing temperature from $17 / 12$ to $33 / 28{ }^{\circ} \mathrm{C}$. Continuous high temperature $\left(33 / 28{ }^{\circ} \mathrm{C}\right)$ had a detrimental effect on germination as measured by a standard germination test and an accelerated aging test. Optimum germination of the progeny occurred at $20 / 15{ }^{\circ} \mathrm{C}$; however, germination rate was faster when seeds matured at $23 / 18{ }^{\circ} \mathrm{C}$. Seeds that developed at $33 / 28{ }^{\circ} \mathrm{C}$ produced seedlings with the lowest vigor, while those which developed at $20 / 15^{\circ} \mathrm{C}$ produced seedlings with the highest vigor. Brief exposure of plants to $33 / 28{ }^{\circ} \mathrm{C}$ during anthesis or early seed development was as detrimental to seed yield as continuous exposure to $33 / 28^{\circ} \mathrm{C}$. Exposure to high temperature $\left(33 / 28^{\circ} \mathrm{C}\right)$ during late seed development had less effect on seed yield, and seed quality was improved. Progeny vigor was reduced greatly by seed development at continuous high temperature $\left(33 / 28^{\circ} \mathrm{C}\right)$, but was unaffected by brief exposure to $33 / 28{ }^{\circ} \mathrm{C}$ at anthesis, early, or late in seed development. These results suggest that high $\left(33 / 28^{\circ} \mathrm{C}\right)$ day/night temperatures during pollination, fertilization, or early stages of seed development can greatly reduce carrot seed yield and seed quality.
\end{abstract}

Seed yield, seed quality, and seedling vigor are influenced by the growing environment of the mother plant (Austin, 1972). Effects of temperature on flower initiation, flowering, and seed production of many agronomic and horticultural crops has long been recognized (Went, 1953). Temperature appears to be the primary environmental factor that influences a seed crop from the vegetative phase to all stages of seed development and maturation.

Moderate to high seed maturation temperatures, compared to seed that matured under cool conditions, increased the germination capacity of freshly harvested seeds of sugarbeet (Wood et al., 1980), lettuce (Harrington and Thompson, 1952; Koller, 1962), barley (Khan and Laude, 1969), forage grasses (Akpan and Bean, 1977), hybrid rose (Van Abrams and Hand, 1956), and alfalfa (Austin, 1972).

Research on carrot seed production has dealt mainly with temperature effects during the early stages of seed development such as flower initiation, seedstalk development, and sex expression. Sakr and Thompson (1942) reported that growth temperatures of 10 to $15{ }^{\circ} \mathrm{C}$ following vernalization resulted in $60 \%$ to $100 \%$ flowering and was more favorable to reproductive growth in 'French Forcing' carrot than 15 to 21 or 21 to $27^{\circ} \mathrm{C}$. Dickson and Peterson (1958) found that, following cold storage of the roots, plants grown at $13{ }^{\circ} \mathrm{C}$ bolted earlier and produced more flowers than those plants grown at $18^{\circ} \mathrm{C}$.

Quagliotti (1967) studied the influence of temperature on seedstalk development and sex expression in 'Amsterdam Forcing' carrot. At high temperature $\left(26^{\circ} \mathrm{C}\right)$, plants flowered earlier, but the seedstalk was weak. At low growing temperature $\left(14^{\circ} \mathrm{C}\right)$, the total number of flowers and fertile hermaphroditic flowers were more than twice the number obtained at $26^{\circ} \mathrm{C}$. The proportion of male flowers was higher at 26 than $14{ }^{\circ} \mathrm{C}$. Eisa and Wallace (1969) reported that high temperature increased petaloidy in carrots and decreased seedstalk height.

Received for publication 20 Feb. 1996. Accepted for publication 22 June 1996. Florida Agricultural Experiment Station journal series R-05016. The cost of publishing this paper was defrayed in part by the payment of page charges. Under postal regulations, this paper therefore must be hereby marked advertisement solely to indicate this fact.

${ }^{1}$ Current address: Dept. of Horticulture, Faculty of Agriculture, Shambat, Sudan.
The purpose of the present study was to investigate the effect of different growing temperatures on seedstalk development, seed yield, and seed quality in carrots.

\section{Materials and Methods}

Carrot (Daucus carota 'Hicolar 9') stecklings were grown on raised beds at the Horticultural Unit at the Univ. of Florida, Gainesville, on a fine sandy soil. After harvest in August, medium, uniform stecklings were selected and washed, and tops were cut to about $6 \mathrm{~cm}$ long and roots to about $12 \mathrm{~cm}$ long. Stecklings were dipped in $0.2 \%$ Thiram solution and stored in vermiculite mixture for 8 weeks at $5{ }^{\circ} \mathrm{C}$ (Elballa and Cantliffe, 1987).

Experiment 1: The influence of growing temperature on seedstalk development, seed yield, and seed quality. Carrot stecklings were planted in 8 -L pots filled with 3 peat : 1 perlite mixture and grown in a greenhouse under a 14 -h photoperiod at $25 / 20^{\circ} \mathrm{C}$ day/night temperatures. At seedstalk initiation, uniform plants were transferred to growth chambers (Conviron E-15) in which the day/night temperatures were set at $33 / 28,28 / 23,25 / 20,23 / 18,20 / 15$, and $17 /$ $12^{\circ} \mathrm{C}$. Light intensities of 775 and $600 \mu \mathrm{mol} \cdot \mathrm{m}^{-2} \cdot \mathrm{s}^{-1}$ at the primary umbel level and the pot level, respectively, and photoperiod (14 h) were provided equally in all chambers. Plants were fertilized every week with a $20 \mathrm{~N}-9 \mathrm{P}-17 \mathrm{~K}$ solution applied through a drip system at a rate of $20 \mathrm{~g} / 3.7 \mathrm{~L}$. Each plant received $200 \mathrm{~mL}$ of this solution. Otherwise, general irrigation was done when needed. Relative humidity (RH) was maintained at $70 \%$ during vegetative and early reproductive stages, then reduced to $40 \%$ when seeds on the primary umbel started to mature. The experiment was a completely randomized design, with 10 replicates (plants) in each chamber.

Plants were tagged at the date of anthesis of the first flower on the primary umbel. Flowers were hand-pollinated in the morning and late afternoon. Seeds were harvested when those on the tertiary umbels reached maturity (i.e., after 55, 70, and $90 \mathrm{~d}$ from primary umbel anthesis for $33 / 28,28 / 33^{\circ} \mathrm{C}$, and all remaining treatments, respectively). They were then threshed, cleaned by hand and stored at $10{ }^{\circ} \mathrm{C}$ and $20 \% \mathrm{RH}$.

Germination and mean days to germination (MDG) were deter- 
mined using a germination test and accelerated aging tests. For the accelerated aging test, at least 100 seeds in four replicates from each umbel order were placed on wire mesh screens in plastic containers above $100 \mathrm{~mL}$ water. The containers were sealed and incubated for $4 \mathrm{~d}$ at $41^{\circ} \mathrm{C}$ and $100 \% \mathrm{RH}$. Seeds then were removed and dried at $15^{\circ} \mathrm{C}$ and $25 \% \mathrm{RH}$ for $7 \mathrm{~d}$.

Seeds were germinated at $25^{\circ} \mathrm{C}$ between moistened Whatman no. 1 and no. 3 filter papers in $9-\mathrm{cm}$ petri dishes. Germination counted (radicles visible) was at 24-h intervals for $14 \mathrm{~d}$. There were four replicates of 25 seeds/petri dish.

Mean days to germination (MDG) were calculated by the formula $\mathrm{MDG}=\sum \mathrm{GiTi} / \sum \mathrm{Gi}$, where $\mathrm{Gi}$ was the number of germinated seeds at day $\mathrm{Ti}$, and $\mathrm{Ti}$ was the I-th day of germination (Gerson and Honma, 1978).

Seedling vigor was determined by measuring the lengths, fresh weights, and dry weights of radicles and hypocotyls on four replicates of 10 seedlings after $14 \mathrm{~d}$.

Experiment 2: The influence of temperature stress during various growth stages on seed yield and seed quality. The objective of this experiment was to investigate the effect of a brief exposure to high temperature at three stages of seed development on seed yield and seed quality.

Carrot stecklings were grown as previously described (Elballa and Cantliffe, 1987) in growth chambers set at $20 / 15^{\circ} \mathrm{C}$ day/night. After seedstalk initiation, uniform plants were selected and exposed to one of the following treatments: continuous high temperature $\left(33 / 28^{\circ} \mathrm{C}\right)$, continuous low temperature $\left(20 / 15^{\circ} \mathrm{C}\right)$, transfer from $20 / 15$ to $33 / 28^{\circ} \mathrm{C}$ at flower anthesis, transfer from $20 / 15$ to $33 / 28{ }^{\circ} \mathrm{C}$ at early seed development (10 d after flower anthesis), and transfer from $20 / 15$ to $33 / 28^{\circ} \mathrm{C}$ at late seed development (30 $\mathrm{d}$ after flower anthesis). After exposure to the high-temperature treatment $\left(33 / 28^{\circ} \mathrm{C}\right)$ for $10 \mathrm{~d}$, plants in treatments 3,4 , and 5 were returned to low temperatures $\left(20 / 15^{\circ} \mathrm{C}\right)$ until harvest. Each treatment had six replications.

Each umbel was tagged, and all umbels undergoing the hightemperature treatment were harvested and used for subsequent seed quality testing. Seed yield and seeds per single umbel on each umbel order were counted. Seed germination and vigor were evaluated as described previously.

\section{Results and Discussion}

Experiment 1: Flowering and seedstalk development. Days to primary umbel anthesis decreased linearly as seed developmental temperature increased from $17 / 12$ to $33 / 28^{\circ} \mathrm{C}$ (Table 1). Flowers on the primary umbel reached anthesis $48 \mathrm{~d}$ after planting when grown at $33 / 28{ }^{\circ} \mathrm{C}$ compared to $77 \mathrm{~d}$ when grown at $17 / 12{ }^{\circ} \mathrm{C}$. These results are similar to those of Quagliotti (1967) in that plants grown at $26{ }^{\circ} \mathrm{C}$ flowered earlier than those grown at $14{ }^{\circ} \mathrm{C}$. Similarly, Hiller and Kelly (1979) found that bolting was quicker and umbel formation was completed earlier in plants kept at 27/21 or $32 / 27$ than at $21 / 15^{\circ} \mathrm{C}$.

Growth at $33 / 28^{\circ} \mathrm{C}$ reduced the final seedstalk height compared to plants grown at low temperatures (Table 1). However, the relationship between temperature and seedstalk height was nonlinear. Similar effects of postvernalization (Hiller and Kelly, 1979; Quagliotti, 1967) and postanthesis temperature stress have been reported. Dickson and Peterson (1958) reported that reproductive development rate in carrots was increased by high temperatures $\left(27 / 21^{\circ} \mathrm{C}\right)$. The effects of high temperature on seedstalk height may be attributable in part to decreased gibberellin-like activity in the shoot apex. Hiller et al. (1979) found reduced gibberellin-like activity as postvernalization temperature increased from $21 / 15$ to $32 / 27^{\circ} \mathrm{C}$.

Total umbels per plant and number of umbels on the secondary, tertiary, and quaternary umbels decreased linearly as growth temperature increased from $17 / 12$ to $33 / 28{ }^{\circ} \mathrm{C}$ (Table 1). For a description of flowering patterns in carrot, see Borthwick (1931). The number of umbels on the secondary, tertiary, and quaternary orders was reduced by about 38\%, 47\%, and 50\%, respectively, whereas the number of umbels per plant was reduced by $44 \%$ at $33 /$ 28 compared to $17 / 12{ }^{\circ} \mathrm{C}$. Increasing the temperature from $17 / 12$ to $25 / 20^{\circ} \mathrm{C}$ had no effect on the number of umbels on the secondary and tertiary orders or total number of umbels per plant; however, an increase in temperature from $17 / 12$ to $23 / 18{ }^{\circ} \mathrm{C}$ reduced the number of umbels on the quaternary umbel orders. These results agree with those results of Hiller and Kelly (1979) who reported that high temperature reduced the development of lateral branches and decreased the total number of umbels.

Effects of growing temperature on seed yield. Seed fresh weight per plant and seed fresh weight per umbel order decreased as the temperature during seed development increased from 20/15 to 33/ $28^{\circ} \mathrm{C}$ (Table 2). Total seed number per plant and seed number on each umbel order were affected by growth temperature in a similar pattern to seed weight (data not shown). Plants kept at $33 / 28{ }^{\circ} \mathrm{C}$ were almost barren, which may reflect poor pollen viability and increased male sterility. Pollen viability is higher when carrot plants are grown at low temperature (Quagliotti, 1967). High occurrence of petaloidy and a decrease in the ratio of hermaphroditic to male flowers may occur at high temperatures (Eisa and Wallace, 1969; Quagliotti, 1967). Poor seed set at high temperatures in onions was associated with pollen sterility and abnormal embryo and endosperm development (Chang and Struckmeyer, 1975; 1976a, 1976b).

Seed germination and seedling growth. Germination of primary umbel nonaged seed was reduced when plants were grown at $33 / 28$ and $17 / 12^{\circ} \mathrm{C}$ compared to intermediate regimes (Table 3 ).

Table 1. Effect of temperature during seed development on number of days to primary umbel anthesis, seedstalk height, number of umbels per each order, and number of umbels per plant.

\begin{tabular}{|c|c|c|c|c|c|c|}
\hline \multirow{2}{*}{$\begin{array}{l}\text { Day/night } \\
\text { temp } \\
\left({ }^{\circ} \mathrm{C}\right)\end{array}$} & \multirow{2}{*}{$\begin{array}{c}\text { Days to } \\
\text { primary umbel } \\
\text { anthesis }\end{array}$} & \multirow{2}{*}{$\begin{array}{c}\text { Seedstalk } \\
\text { ht } \\
(\mathrm{cm})\end{array}$} & \multicolumn{3}{|c|}{ No. of umbels/order } & \multirow{2}{*}{$\begin{array}{l}\text { Total no. } \\
\text { of umbels } \\
\text { per plant }\end{array}$} \\
\hline & & & $2^{\circ}$ & $3^{\circ}$ & $4^{\circ}$ & \\
\hline $17 / 12$ & 77 & 73 & 8 & 19 & 22 & 50 \\
\hline $20 / 15$ & 71 & 68 & 7 & 19 & 18 & 46 \\
\hline $23 / 18$ & 62 & 79 & 7 & 16 & 14 & 38 \\
\hline $25 / 20$ & 64 & 63 & 6 & 17 & 16 & 40 \\
\hline $28 / 23$ & 52 & 66 & 6 & 13 & 14 & 34 \\
\hline $33 / 28$ & 48 & 55 & 5 & 10 & 11 & 28 \\
\hline Significance & $\mathrm{L}^{* *}$ & NS & $\mathrm{L}^{* *}$ & $\mathrm{~L}^{* *}$ & $\mathrm{~L}^{* *}$ & $\mathrm{~L}^{* *}$ \\
\hline
\end{tabular}

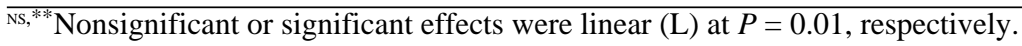


Table 2. Effect of temperature during seed development on seed yield for each umbel order and total yield per plant.

\begin{tabular}{|c|c|c|c|c|c|}
\hline \multirow{2}{*}{$\begin{array}{l}\text { Day/night } \\
\text { temp } \\
\left({ }^{\circ} \mathrm{C}\right)\end{array}$} & \multicolumn{4}{|c|}{ Umbel order } & \multirow{2}{*}{$\begin{array}{c}\text { Total } \\
\text { seed wt } \\
\text { per plant }\end{array}$} \\
\hline & $1^{\circ}$ & $2^{\circ}$ & $3^{\circ}$ & $4^{\circ}$ & \\
\hline & \multicolumn{4}{|c|}{ Seed $w t(\mathrm{gm})$} & \\
\hline $17 / 12$ & 3.3 & 4.8 & 2.3 & 0.22 & 10.7 \\
\hline $20 / 15$ & 4.8 & 6.6 & 3.4 & 0.47 & 15.4 \\
\hline $23 / 18$ & 1.4 & 4.9 & 1.2 & 0.01 & 7.5 \\
\hline $25 / 20$ & 1.3 & 3.1 & 1.0 & 0.42 & 5.8 \\
\hline $28 / 23$ & 0.7 & 1.8 & 0.5 & 0.17 & 3.1 \\
\hline $33 / 28$ & 0.1 & 0.2 & 0.1 & 0.00 & 0.3 \\
\hline Significance & $\mathrm{L}^{*}$ & $\mathrm{~L}^{* *}$ & $\mathrm{~L}^{*}$ & NS & $\mathrm{L}^{*}$ \\
\hline
\end{tabular}

$\overline{\mathrm{Ns}}^{*},{ }^{* * *}$ Nonsignificant or significant linear (L) effects at $P=0.05$ or 0.01 , respectively.

Secondary and tertiary umbel seed germination was only reduced when developmental temperature was $33 / 28^{\circ} \mathrm{C}$.

Accelerated aging reduced the germination percentage of primary umbel seeds, irrespective of developmental temperature. The reduction in germination percentage was generally more severe at $17 / 12$ and $33 / 28^{\circ} \mathrm{C}$ than at intermediate developmental temperatures. Accelerated aging of seeds from the secondary and tertiary umbels caused less reduction in germination percentage than those on the primary umbel seeds. Secondary and tertiary umbel seeds that developed at $33 / 28^{\circ} \mathrm{C}$ had the lowest germination percentage after aging.

Averaged over umbel orders and aging, seeds that developed at $20 / 15$ or $23 / 18^{\circ} \mathrm{C}$ had the highest germination percentage, while those that developed at $33 / 28$ or $17 / 12^{\circ} \mathrm{C}$ had the lowest germination percentage. Thomas and Raper (1975a, 1975b) reported that tobacco mother plants grown under high temperatures $\left(30 / 26^{\circ} \mathrm{C}\right)$ produced seeds with lower germination percentage than those plants grown under low temperatures $\left(22 / 18{ }^{\circ} \mathrm{C}\right)$. Heat stress during barley seed development severely decreased germination percentage of the freshly harvested seeds (Khan and Laude, 1969). On the other hand, warm conditions during seed development have increased seed germinability (Evenari, 1965; Khan and Laude, 1969; Stearns, 1960). Carrot seeds that developed at a day/night temperature of $30 / 20{ }^{\circ} \mathrm{C}$ germinated and emerged earlier than seeds that developed at $20 / 10^{\circ} \mathrm{C}$ (Gray et al. 1988).

Germination rate of primary and secondary umbel nonaged seeds was delayed by developmental temperatures of $33 / 28$ and $17 / 12{ }^{\circ} \mathrm{C}$ compared to intermediate temperatures (Table 3). Tertiary umbel seed germination was most rapid in seed produced at $23 / 18^{\circ} \mathrm{C}$. There was no difference among the other developmental temperatures.

After accelerated aging, germination of seed produced on all umbel orders was delayed. The delay in germination was usually least for seeds that developed at $23 / 18^{\circ} \mathrm{C}$ (Table 3 ). Tobacco seeds produced at higher temperatures $\left(30 / 26^{\circ} \mathrm{C}\right)$ were slower to germinate than those produced under low temperatures $\left(22 / 18{ }^{\circ} \mathrm{C}\right)$ (Thomas and Raper, 1975a, 1975b). Similarly, low temperature $\left(15 / 10^{\circ} \mathrm{C}\right)$ during seed development resulted in a low rate of germination of many forage grasses (Akpan and Bean, 1977).

Seeds on all orders that developed at high temperature $(33 / 28$ ${ }^{\circ} \mathrm{C}$ ) had the shortest radicles and hypocotyls (Table 4). Seeds that developed at $25 / 20^{\circ} \mathrm{C}$ produced seedlings with the greatest vigor. Seedlings of forage grasses and tobacco were always larger from

Table 3. Effect of temperature during seed development, umbel order, and seed aging on germination percentage and mean days to germination (MDG) at $25^{\circ} \mathrm{C}$.

\begin{tabular}{|c|c|c|c|c|c|c|}
\hline \multirow{3}{*}{$\begin{array}{l}\text { Day/night } \\
\text { temp } \\
\left({ }^{\circ} \mathrm{C}\right)\end{array}$} & \multicolumn{6}{|c|}{ Umbel } \\
\hline & \multicolumn{2}{|c|}{ Primary } & \multicolumn{2}{|c|}{ Secondary } & \multicolumn{2}{|c|}{ Tertiary } \\
\hline & Nonaged & Aged & Nonaged & Aged & Nonaged & Aged \\
\hline & \multicolumn{6}{|c|}{ Total germination $(\%)^{z}$} \\
\hline $17 / 12$ & 84 & 05 & 98 & 48 & 96 & 45 \\
\hline $20 / 15$ & 100 & 41 & 98 & 62 & 94 & 86 \\
\hline $23 / 18$ & 97 & 63 & 95 & 60 & 99 & 56 \\
\hline $25 / 20$ & 94 & 07 & 99 & 64 & 91 & 20 \\
\hline $28 / 23$ & 94 & 33 & 99 & 62 & 94 & 61 \\
\hline $33 / 28$ & 53 & 17 & 71 & 05 & 79 & 10 \\
\hline \multirow[t]{2}{*}{ Significance } & $\mathrm{L}^{* *} \mathrm{Q}^{* *}$ & $Q^{*}$ & $\mathrm{~L}^{*} \mathrm{Q}^{*}$ & $\mathrm{~L}^{* *} \mathrm{Q}^{* * *}$ & $\mathrm{~L}^{* *} \mathrm{Q}^{* *}$ & $\mathrm{~L}^{* *}$ \\
\hline & \multicolumn{6}{|c|}{ Mean days to germination ${ }^{y}$} \\
\hline $17 / 12$ & 4.3 & 7.8 & 4.1 & 8.1 & 3.5 & 7.7 \\
\hline $20 / 15$ & 2.7 & 7.5 & 2.7 & 5.7 & 4.2 & 7.9 \\
\hline $23 / 18$ & 3.2 & 5.9 & 3.5 & 6.8 & 2.9 & 5.9 \\
\hline $25 / 20$ & 3.1 & 8.0 & 2.6 & 6.8 & 3.3 & 7.3 \\
\hline $28 / 23$ & 3.6 & 8.0 & 3.6 & 8.1 & 3.9 & 7.0 \\
\hline $33 / 28$ & 4.2 & 7.8 & 4.5 & 8.1 & 3.4 & 9.8 \\
\hline Significance & $\mathrm{Q}^{* * *}$ & & $\mathrm{~L}^{* *} \mathrm{Q}^{* *}$ & $\mathrm{Q}^{*}$ & & $\mathrm{~L}^{* *} \mathrm{Q}^{* * *}$ \\
\hline
\end{tabular}


Table 4. Effect of temperature during seed development and umbel order on subsequent radicle and hypocotyl lengths of seedlings grown at $25^{\circ} \mathrm{C}$ for $14 \mathrm{~d}$.

\begin{tabular}{lccc}
\hline \hline $\begin{array}{l}\text { Day/night } \\
\text { temp }\end{array}$ & \multicolumn{3}{c}{ Umbel } \\
\cline { 2 - 4 }$\left({ }^{\circ} \mathrm{C}\right)$ & Primary & Secondary & Tertiary \\
\hline & & Radical length $($ cm $)$ & 7.2 \\
$17 / 12$ & 5.8 & 6.1 & 6.4 \\
$20 / 15$ & 6.7 & 6.3 & 7.1 \\
$23 / 18$ & 6.3 & 6.4 & 7.7 \\
$25 / 20$ & 5.9 & 7.0 & 5.7 \\
$28 / 23$ & 7.0 & 6.4 & 5.1 \\
$33 / 28$ & 1.9 & 3.3 & $\mathrm{~L}^{* *} \mathrm{Q}^{* * *}$ \\
Significance & $\mathrm{L}^{* *} \mathrm{Q}^{* *}$ & $\mathrm{~L}^{* *} \mathrm{Q}^{* *}$ & \\
& & Hypocotyl length $($ cm $)$ & 6.5 \\
$17 / 12$ & 5.5 & 6.2 & 6.4 \\
$20 / 15$ & 6.4 & 6.8 & 6.6 \\
$23 / 18$ & 6.4 & 6.7 & 7.6 \\
$25 / 20$ & 7.0 & 7.1 & 7.0 \\
$28 / 23$ & 7.0 & 6.8 & 5.8 \\
$33 / 28$ & 4.3 & 5.5 & $\mathrm{Q}^{* *}$ \\
Significance & $\mathrm{L}^{* *} \mathrm{Q}^{* *}$ & $\mathrm{~L}^{* *} \mathrm{Q}^{* *}$ & \\
\hline
\end{tabular}

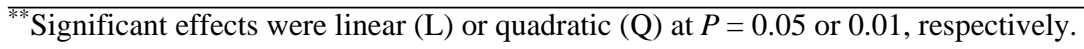

seeds that developed at low temperatures than at high temperature (Akpan and Bean, 1977; Thomas and Raper, 1975a, 1975b).

The influence of temperature stress during various growth stages on seed yield and seed quality. Weight and number of seeds from primary and secondary umbels were reduced by short exposure to continuous high temperature, high temperature at anthesis, or high temperature during early seed development compared to continuous low temperature (Table 5). Whereas seed weight from tertiary umbels was not affected by high temperature at anthesis, fewer seeds were produced after exposure to continuous high temperature or to high temperature at anthesis or during early seed development. However, tertiary umbel seed number was unaffected by temperature.

These results suggest that high temperature effects on microsporogenesis and megasporogenesis may influence seed yield in carrots. Anthesis coincides with pollen development and germination, whereas early stages of seed development coincide with ovule development and endosperm division (Akpan and Bean, 1977; Gray, et al., 1984). A detrimental effect of high temperature stress on zygote formation and ovule development has been reported for bean (Ormrod et al., 1967) and onion (Chang and Struckmeyer, 1976a, 1976b).

Seed germination and seedling growth. Germination of nonaged seeds produced on primary and secondary umbels was severely reduced when parent plants were exposed to continuous high temperature (Table 6). High temperature at anthesis or during early to late seed development had no effect on the germination of primary or secondary umbel seeds. Germination of tertiary umbel seeds was similar when seeds were produced under continuous high or low temperature. Germination was greater in seeds that were exposed to brief high temperature at anthesis or during early or late seed development compared to seeds produced under continuous high or low temperature.

After accelerated aging, primary and secondary umbel seeds

Table 5. Effect of exposure to high temperature $\left(33 / 28^{\circ} \mathrm{C}\right)$ on seed weight and number per single umbel on primary, secondary, and tertiary orders.

\begin{tabular}{lccc}
\hline \hline Stage of & \multicolumn{3}{c}{ Umbel } \\
\cline { 2 - 4 } exposure & Primary & Secondary & Tertiary \\
\hline & & Seed wt $(g)$ & 0.18 \\
Continuous low $\left(20 / 15^{\circ} \mathrm{C}\right)$ & 4.2 & 0.8 & 0.03 \\
Continuous high $\left(33 / 28^{\circ} \mathrm{C}\right)$ & 0.4 & 0.3 & 0.12 \\
Anthesis & 0.2 & 0.1 & 0.09 \\
Early seed development & 0.1 & 0.4 & 0.14 \\
Late seed development & 2.6 & 1.3 & 0.07 \\
LSD $(0.05)$ & 1.3 & 0.4 & 136 \\
& & No. seeds & 12 \\
Continuous low $\left(20 / 15^{\circ} \mathrm{C}\right)$ & 2156 & 400 & 50 \\
Continuous high $\left(33 / 28^{\circ} \mathrm{C}\right)$ & 223 & 132 & 36 \\
Anthesis & 142 & 197 & 69 \\
Early seed development & 84 & 524 & 75 \\
Late seed development & 1182 & 177 & \\
LSD $(0.05)$ & 585 & & \\
\hline
\end{tabular}


Table 6. Effect of exposure to high temperature $\left(33 / 28^{\circ} \mathrm{C}\right)$ on germination and mean days to germination of progeny from different umbel orders, before and after seed aging.

\begin{tabular}{|c|c|c|c|c|c|c|}
\hline \multirow{3}{*}{$\begin{array}{l}\text { Stage of } \\
\text { exposure }\end{array}$} & \multicolumn{6}{|c|}{ Umbrel } \\
\hline & \multicolumn{2}{|c|}{ Primary } & \multicolumn{2}{|c|}{ Secondary } & \multicolumn{2}{|c|}{ Tertiary } \\
\hline & Nonaged & Aged & Nonaged & Aged & Nonaged & Aged \\
\hline & \multicolumn{6}{|c|}{ Total germination $(\%)^{z}$} \\
\hline Continuous low $\left(20 / 15^{\circ} \mathrm{C}\right)$ & 98 & 21 & 92 & 48 & 80 & 35 \\
\hline Continuous high $\left(33 / 28^{\circ} \mathrm{C}\right)$ & 54 & 08 & 69 & 05 & 78 & 10 \\
\hline Anthesis & 90 & 03 & 94 & 27 & 95 & 34 \\
\hline Early seed development & 96 & 10 & 96 & 12 & 93 & 20 \\
\hline \multirow[t]{2}{*}{ Late seed development } & 92 & 75 & 89 & 66 & 95 & 21 \\
\hline & \multicolumn{6}{|c|}{ Mean days to germination ${ }^{y}$} \\
\hline Continuous low $\left(20 / 15^{\circ} \mathrm{C}\right)$ & 3.3 & 11.1 & 3.7 & 7.7 & 3.9 & 9.2 \\
\hline Continuous high $\left(33 / 28^{\circ} \mathrm{C}\right)$ & 3.4 & 8.0 & 2.8 & 9.4 & 3.4 & 8.7 \\
\hline Anthesis & 3.3 & 9.7 & 2.7 & 9.2 & 3.0 & 8.4 \\
\hline Early seed development & 2.8 & 9.4 & 3.0 & 8.7 & 4.4 & 7.2 \\
\hline Late seed development & 3.8 & 6.4 & 3.4 & 6.2 & 4.0 & 9.2 \\
\hline
\end{tabular}

${ }_{\mathrm{Z}} \mathrm{LSD}(0.05)$ for stage $\times$ umbel order $\times$ seed aging $=10 \%$.

$\mathrm{y}_{\mathrm{LSD}}(0.05)$ for stage $\times$ umbel order $\times$ seed aging $=1.1 \mathrm{~d}$.

that were exposed to high temperature late in their development had more germination than seeds produced at other temperatures (Table 6). After aging, seeds from the tertiary umbels germinated poorly regardless of the temperature treatment.

High-temperature stress treatment had no effect on the MDG of nonaged seed produced on the primary and secondary umbels, but a delay of tertiary umbel seed germination resulted from exposure to high temperature early in seed development (Table 6). Hightemperature stress during late seed development enhanced germination rate after a stress-accelerated aging treatment, especially in primary and secondary umbel seeds. Germination rate of freshly harvested barley seed was enhanced by heat stress during the seed maturation stage (Khan and Laude, 1969). This was explained by production of seeds with thinner seed coats and less inhibitor contents. More and faster germination after moderate maturation temperatures also was reported for onion (Gray and Steckel, 1984), lettuce (Harrington and Thompson, 1952; Koller, 1962), and bracted plantain (Stearns, 1960). Fewer seeds were harvested from plants exposed to brief high temperature late in seed development. Possibly, only the highest-quality seed survived high temperature imposed during late seed development.

Seeds that developed under continuous high temperature produced less vigorous seedlings with shorter hypocotyls and radicles and lower weights compared to seeds of other treatments (Table 7). The effect of high temperature on progeny growth was more severe on seeds produced on primary and secondary umbels than on those developed on tertiary umbels. High temperature at anthesis or during early or late seed development had no effect on radicle length. However, hypocotyl length of seedlings produced from primary umbel seed was reduced by exposure to high temperature at anthesis.

The environment during seed development dictates the geographic location of seed production for many crops. Temperature is a primary factor that influences the seed crop from its vegetative phase through seed development and maturation. The few reports on the temperature response in carrot have dealt mainly with the early stages of the seed plant growth. Such reports fall short of evaluating temperature effects on seed yield, seed quality and seedling growth. Gray et al. (1988) exposed developing carrot seeds to temperatures of $20 / 10,25 / 15$, and $30 / 20^{\circ} \mathrm{C}$. Seeds that

Table 7. Effect of exposure to high temperature $\left(33 / 28^{\circ} \mathrm{C}\right)$ on seedling length and seedling weight of the progenies from different umbels.

\begin{tabular}{|c|c|c|c|}
\hline \multirow{2}{*}{$\begin{array}{l}\text { Stage of } \\
\text { exposure }\end{array}$} & \multicolumn{3}{|c|}{ Order } \\
\hline & Primary & Secondary & Tertiary \\
\hline & \multicolumn{3}{|c|}{ Radicle length $(\mathrm{cm})$} \\
\hline Continuous low $\left(20 / 15^{\circ} \mathrm{C}\right)$ & 6.6 & 6.5 & 6.6 \\
\hline Continuous high $\left(33 / 28^{\circ} \mathrm{C}\right)$ & 1.9 & 3.3 & 5.2 \\
\hline Anthesis & 8.5 & 8.4 & 7.2 \\
\hline Early seed development & 8.6 & 8.0 & 6.1 \\
\hline Late seed development & 9.0 & 8.8 & 7.3 \\
\hline \multirow[t]{2}{*}{$\operatorname{LSD}(0.05)$} & 1.4 & 1.0 & 0.9 \\
\hline & \multicolumn{3}{|c|}{ Hypocotyl length (cm) } \\
\hline Continuous low $\left(20 / 15^{\circ} \mathrm{C}\right)$ & 6.6 & 6.7 & 6.7 \\
\hline Continuous high $\left(33 / 28^{\circ} \mathrm{C}\right)$ & 4.3 & 5.6 & 5.8 \\
\hline Anthesis & 6.6 & 6.9 & 6.6 \\
\hline Early seed development & 6.0 & 6.4 & 6.4 \\
\hline Late seed development & 6.7 & 6.1 & 6.0 \\
\hline $\operatorname{LSD}(0.05)$ & 0.5 & 0.7 & 0.9 \\
\hline
\end{tabular}


developed at $30 / 20^{\circ} \mathrm{C}$ had the largest embryos, but there was no effect of temperature on endosperm and embryo weight. Pericarp weight decreased with an increase in temperature and seeds matured in the highest temperature germinated and emerged earlier. The results of our work suggest that continuous high temperature $\left(33 / 28^{\circ} \mathrm{C}\right)$ during pollination, fertilization, and early stages of seed development can greatly reduce carrot seed yield and seed quality. Thus, seeds from those umbels that are not exposed to high temperatures for extended periods of time and that allow the embryo and endosperm to fully mature will most likely be of the highest quality.

\section{Literature Cited}

Akpan, E.E.J. and E.W. Bean. 1977. The effects of temperature upon seed development in three species of forage grasses. Ann. Bot. 41:689-695. Austin, R.B. 1972. Effects of environment before harvesting on viability, p. 114-119. In: E.R. Roberts (ed.). Viability of seed. Syracuse Univ. Press, Syracuse, New York.

Borthwick, H.A. 1931. Carrot seed germination. Proc. of the Amer. Soc. for Hort. Sci. 28:310-314.

Chang, W.M. and B.E. Struckmeyer. 1975. The influence of temperature and relative humidity on onion pollen germination. HortScience 10:162163.

Chang, W.M. and B.E. Struckmeyer. 1976a. Influence of temperature, time of day and flower age on pollen germination, stigma receptivity, pollen tube growth and fruit set of Allium cepa L. J. Amer. Soc. Hort. Sci. 101:81-83.

Chang, W.M. and B.E. Struckmeyer. 1976b. Influence of temperature on seed development of Allium cepa. L. J. Amer. Soc. Hort. Sci. 101:296298.

Dickson, M.H. and C.E. Peterson. 1958. Hastening greenhouse seed production for carrot breeding. Proc. Amer. Soc. Hort. Sci. 71:412-415.

Eisa, H.M. and D.H. Wallace. 1969. Factors influencing petaloidy expression in carrot, Daucus carota L. J. Amer. Soc. Hort. Sci. 94:647-649.

Elballa, M. and D.J. Cantliffe. 1987. Effect of growth regulators on flowering, number of umbels, seed yield and seed quality of carrot (Daucus carota). Acta Hort. 198:163-170.

Evenari, M. 1965. Physiology of seed dormancy, after ripening and germination. Proc. Intl. Seed Testing Assn. 30:49-71.

Gerson, R. and S. Honma. 1978. Emergence response of the pepper at low soil temperature. Euphytica 27:1757-1762.

Gray, D. and J.R.A. Steckel. 1984. Viability of onion (Allium cepa) seed as influenced by temperature during seed growth. Ann. Appl. Bot. 104:375-382.

Gray, D., J.R.A. Steckel, J. Dearman, and P.A. Brocklehurst. 1988. Some effects of temperature during seed development on carrot (Daucus carota) seed growth and quality. Ann. Appl. Bot. 112:367-376.

Gray, D., J.A. Ward, and J.R.A. Steckel. 1984. Endosperm and embryo development in Daucus carota L. J. Expt. Bot. 35:459-465.

Harrington, J.P. and R.S. Thompson. 1952. Effects of variety and areas of production on subsequent germination of lettuce seed at high temperature. Proc. Amer. Soc. Hort. Sci. 59:445-450.

Hiller, L.V. and W.C. Kelly. 1979. The effect of post-vernalization temperature on seedstalk elongation and flowering in carrots. J. Amer. Soc. Hort. Sci. 104:253-257.

Hiller, L.K., W.C. Kelly, and L.E. Powell. 1979. Temperature interactions with growth regulators and endogenous gibberellin-like activity during seedstalk elongation in carrot. Plant Physiol. 63:1055-1061.

Khan, A.R. and H.M. Laude. 1969. Influence of heat stress during seed maturation on germinability of barley seed at harvest. Crop Sci. 9:55-58.

Koller, D. 1962. Preconditioning of germination in lettuce at time of fruit ripening. Amer. J. Bot. 48:841-844.

Ormrod, D.P., C.J. Wooley, G.W. Eaton, and E.H. Stabble. 1967. Effect of temperature on embryo sac development in Phaseolus vulgaris $\mathrm{L}$. Can. J. Bot. 45:948-950.

Quagliotti, L. 1967. Effects of different temperatures on stalk development, flowering habit and sex expression in the carrot Daucus carota $\mathrm{L}$. Euphytica 16:83-103.

Sakr, E.S. and H.C. Thompson. 1942. Effect of temperature and photoperiod on seedstalk development in carrot. Proc. Amer. Soc. Hort. Sci. 41:343-346.

Stearns, F. 1960. Effects of seed environment during maturation on seedling growth. Ecol. 41:221-222.

Thomas, J.F. and C.D. Raper, Jr. 1975a. Differences in the progeny of tobacco due to temperature treatment of the mother plant. Tobacco Sci. 19:37-41.

Thomas, J.F. and C.D. Raper, Jr. 1975b. Seed germinability as affected by the environmental temperature of the mother plant. Tobacco Sci. 19:104106.

Van Abrams, G.J. and M.E. Hand. 1956. Seed dormancy in Rosa as a function of climate. Amer. J. Bot. 43:7-12.

Went, F.W. 1953. The effect of temperature on plant growth. Annu. Rev. Plant Physiol. 4:347-362.

Wood, D.W., R.V. Scott, and P.C. Longden. 1980. The effects of mother plant temperature on seed quality in Beta vulgaris L. (sugar beet) In: P.D. Hebblethwaite (ed.). Seed production. Butterworth Ltd., London. 